\title{
25. SULFUR AND SULFUR ISOTOPE CONTENT OF BASALTS FROM THE GALAPAGOS RIFT (LEGS 54 AND 70) ${ }^{1}$
}

\author{
Hans-W. Hubberten, Institut für Petrographie und Geochemie der Universität, (TH) Karlsruhe, \\ D-7500 Karlsruhe, Federal Republic of Germany
}

\begin{abstract}
Sixty-four determinations of sulfur isotopes were conducted on basalts from the Galapagos Rift (Deep Sea Drilling Project Legs 54 and 70 ). With a $\sigma$ mean of $-0.3 \%$, primary sulfides reflect the isotopic value of mantle sulfur. The sulfur from sulfate and pyrite shows a wide $\sigma$ spread from $-19.5 \%$ to $+9.7 \%$, reflecting such secondary influences as seawater alteration or precipitation of dissolved primary sulfides. There is no relation between the composition of sulfur isotopes and the sulfur content of the basalts.

Sulfur content varies between 850 and $1714 \mathrm{ppm}$ for the young FETI-basalts and between 164 and $1030 \mathrm{ppm}$ for the normal tholeites of the old Galapagos crust. It is correlated positively with iron content; lower amounts of sulfur compared to iron are either caused by a bulk loss of sulfur resulting from remobilization of igneous sulfides or by the fact that the interior of a pillow, as compared to its rim, is depleted in sulfur.
\end{abstract}

\section{INTRODUCTION}

Since the degassing of volatile substances is inhibited by water pressure, the sulfur content of basalts that erupted on the deep ocean floor is significantly higher than that of basalts that erupted subaerially (Moore and Fabbi, 1971).

The sulfur in submarine basalts occurs in several forms (Czamanske and Moore, 1977; Mathez, 1976): as sulfide globules in glass or the crystalline matrix, as a dissolved constituent in basaltic glass, as irregular grains of sulfides, and as secondary sulfides coating the walls of vesicles or in veins.

Primary sulfate groups can occur in silicates, depending on the oxygen fugacity of the melt (Schneider, 1970). Basaltic melts commonly erupt in a sulfursaturated or nearly saturated state (Mathez, 1976). The sulfur content is strongly influenced by the iron content in the melt, as was shown by Mathez (1976) and Czamanske and Moore (1977) for basaltic glass.

The basalts we retrieved during Leg 70 range from "normal" oceanic tholeiites with a lower iron content [total iron as $\mathrm{FeO}\left(\mathrm{FeO}^{*}\right)=8.2-9.0 \%$ ] to fractionated ferrobasalts (Sites $506,507,508$ ) with a higher iron content $\left(\mathrm{FeO}^{*}=11.7-13.5 \%\right.$; Emmermann et al., this volume).

An increase in sulfur content is expected during the shallow fractional crystallization that forms the ferrobasalts of the young Galapagos crust from the normal ridge tholeiites (Site 510; cf. Mathez, 1976). Investigations on the sulfur isotope composition of primary sulfides in oceanic tholeiites have shown that there is only a slight variation around the meteoritical value (Kanehira et al., 1973; Grinenko et al., 1975; Puchelt and Hubberten, 1980; Hubberten and Puchelt, 1980).

\footnotetext{
${ }^{1}$ Honnorez, J., Von Herzen, R. P., et al., Init. Repts. DSDP, 70: Washington (U.S Govt. Printing Office).
}

A slight shift toward heavier sulfur isotope values may occur during fractionation of basaltic melts (Schneider, 1970; Wedepohl and Muramatsu, 1979).

In this study I have tried to determine whether there is any correlation between the sulfur content and the sulfur isotope ratios in basalts ranging from normal tholeiites to ferrobasalts.

\section{SAMPLE DESCRIPTION}

For these investigations, I selected the freshest possible material on the basis of visual observations while aboard ship.

With respect to the chemical alteration parameters of basalts (Emmermann and Puchelt, 1980), all of the samples are considered to be fresh, with $\mathrm{K}_{2} \mathrm{O}<0.18 \%$, $\mathrm{H}_{2} \mathrm{O}^{+}<0.48 \%$, and $\mathrm{CO}_{2}<0.18 \%$ (Emmermann et al., this volume). From the young FETI-basalts, I selected 15 samples from Site 424 (Leg 54) in addition to 3 samples from Hole 506G, and 4 samples from Hole 507B. Twelve samples from older Galapagos crust at Site 510 and 13 from Site 425 (Leg 54) were also analyzed.

The young FETI-basalts are fine- to medium-grained, aphyric, to sparsely plagioclase phyric basalts, displaying glassy to intergranular textures. Plagioclase is the dominant phenocryst phase with very subordinate clinopyroxene. Titanomagnetite, the dominant opaque phase, is often accompanied by primary sulfide globules; pyrite is rare, occurring in fractures or voids. The old Galapagos crust basalts are fine- to medium-grained, moderately plagioclase, sparsely olivine phyric basalts. Titanomagnetite is less abundant than in the FETI-basalts, but primary sulfide globules occur in the same abundance. Secondary pyrites occur as fracture fillings and in voids in greater amounts than in the young basalts.

For detailed petrographic and geochemical descriptions see Srivastava et al. (1980) and Emmermann et al. (this volume). 


\section{ANALYTICAL PROCEDURE}

The samples were cleaned with distilled water, crushed, and fine milled ( $<200$ mesh) for analysis.

The total sulfur content was determined by combustion in oxygen, using a Strohlein Coulomat 701; this was followed by coulometric titration of the sulfur dioxide by a procedure modified (Erzinger, personal communication) after Lange and Brumsack (1977). The total error of the determinations is less than $\pm 15 \%$.

Sulfur isotope determination was made according to the method described by Puchelt and Hubberten (1980). In this two-step procedure, sulfides such as pyrrhotite, chalcopyrite, or other sulfides of the $\mathrm{Fe}-\mathrm{Cu}-(\mathrm{Ni})-\mathrm{S}$ system are first decomposed by treatment with hydrochloric acid in the presence of aluminum. Pyrite is not attacked in this step. In the second step, the sample (which still contains sulfate and pyrite) is disintegrated with a reducing acid mixture (Thode et al., 1961). The sulfur obtained by this step is termed "pyrite-sulfate" sulfur throughout this chapter-the quotation marks indicating that the substance is a mixture of pyrite sulfur and sulfate sulfur. The sulfur is expelled as $\mathrm{H}_{2} \mathrm{~S}$, which is then precipitated as CdS. This compound is oxidized to form the measuring gas $\mathrm{SO}_{2}$ for mass spectrometry (cf. Ricke, 1964).

Ratio measurements were conducted on a VG-Micromass $1202 \mathrm{~S}$ mass spectrometer. The total error (preparation and measurement) of these determinations is less than $\pm 0.2 \%$ for samples of normal size; it can reach $\pm 1 \%$ for undersized samples. Results are given in the usual $\delta$ notation with respect to the Canon Diablo standard.

\section{Sulfur Content}

\section{RESULTS}

The results of the sulfur content determinations on 18 samples appear in Table 1 and are shown as a function of $\mathrm{FeO}^{*}$ in Figure 1. The sulfur content covers a broad range from 164 to $1710 \mathrm{ppm}$, with lower values in samples from the older Galapagos crust than from those from the FETI-basalts. Sulfur and iron content is positively correlated, although variations within the individual holes can be observed.

\section{Sulfur Isotopes}

The results for the sulfur isotope determinations on 19 samples from Leg 70 are given in Table 1 ; in Table 2 30 previously unpublished values for samples from the Galapagos Rift drilled during Leg 54 are also given. All sulfur istope values for sulfide sulfur (left side of the

Table 1. Sulfur isotope values, total sulfur, and total iron (as $\mathrm{FeO}^{*}$ ), Leg 70.

\begin{tabular}{|c|c|c|c|c|c|}
\hline \multirow{2}{*}{$\begin{array}{l}\text { Laboratory } \\
\text { Sample }\end{array}$} & \multirow{2}{*}{$\begin{array}{l}\text { DSDP Sample } \\
\text { (interval in cm) }\end{array}$} & \multicolumn{2}{|c|}{$\delta^{34} \mathrm{~S}\left(\%_{0}\right)$} & \multirow{2}{*}{$\begin{array}{c}\text { Total S } \\
\text { (ppm) }\end{array}$} & \multirow{2}{*}{$\begin{array}{l}\mathrm{FeO}^{*} \\
(\%)\end{array}$} \\
\hline & & Sulfide-S & "Pyrite-Sulfate"-S & & \\
\hline 5201 & 506G-2-1, 65-69 & -0.1 & +2.2 & 1360 & 11.9 \\
\hline 5202 & $506 \mathrm{G}-2-1,123-124$ & -0.7 & +0.5 & 1100 & 11.7 \\
\hline 5241 & $506 \mathrm{G}-2-1,69-72$ & +0.2 & nd & 1080 & 11.8 \\
\hline 5211 & 507B-1-1, 2-5 & -1.4 & -0.9 & 1710 & 13.1 \\
\hline 5212 & $507 \mathrm{~B}-1-1,15-18$ & -1.6 & +2.2 & 1690 & 13.5 \\
\hline 5213 & $507 \mathrm{~B}-1-1,26-28$ & +0.3 & +1.6 & 1370 & 12.7 \\
\hline 5243 & 507B-2-1, 16-18 & +1.3 & +6.6 & 850 & 12.6 \\
\hline 5221 & $510-9-1,21-25$ & -4.1 & -1.4 & 653 & 8.45 \\
\hline 5222 & $510-9-1,90-93$ & +0.8 & +1.0 & 1030 & 8.25 \\
\hline 5223 & $510-9-2,3-6$ & -0.1 & +6.2 & 762 & 8.53 \\
\hline 5224 & $510-9-2,16-18$ & -1.9 & +3.9 & 365 & 8.49 \\
\hline 5225 & $510-9-2,91-93$ & -2.2 & -1.0 & 721 & 8.62 \\
\hline 5251 & $510-9-2,97-101$ & nd & +7.0 & 164 & 9.01 \\
\hline 5226 & $510-9-3,3-6$ & +2.8 & -19.5 & 889 & 8.40 \\
\hline 5227 & $510-10-1,21-23$ & -1.9 & +0.3 & 807 & 8.66 \\
\hline 5228 & $510-10-169-83$ & -0.2 & +7.3 & 259 & 8.72 \\
\hline 5229 & $510-11-1,21-24$ & +1.9 & +9.7 & 807 & 8.48 \\
\hline 5230 & $510-11-1,42-45$ & nd & +7.7 & 338 & 8.40 \\
\hline 5231 & $510-11-1,48-51$ & +1.7 & +7.5 & nd & 8.45 \\
\hline
\end{tabular}

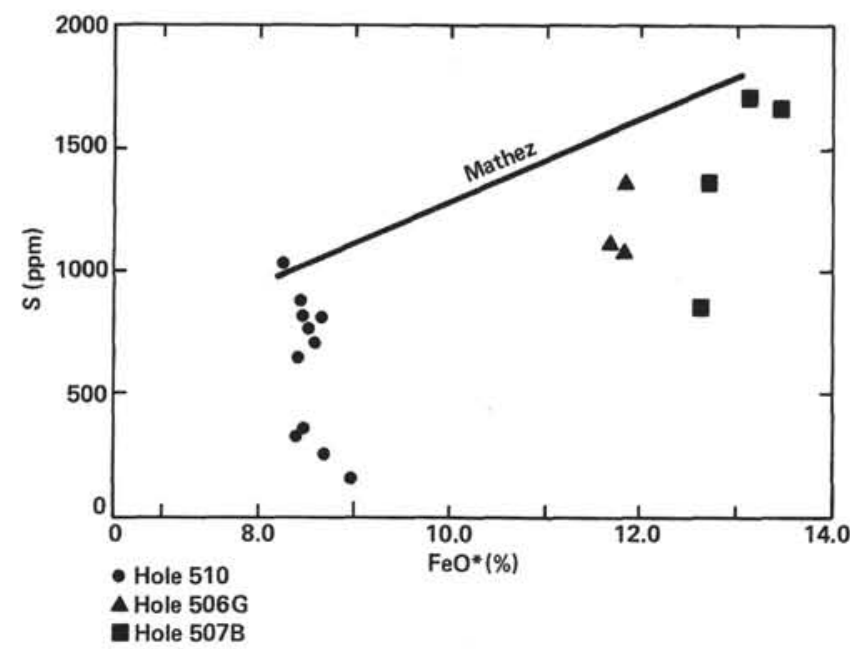

Figure 1. Total sulfur content (ppm) versus total iron content as $\mathrm{FeO}^{*}$ $(\%)$. The Fe-S curve is taken from Mathez (1976).

Table 2. Sulfur isotope values for Galapagos samples, Leg 54.

\begin{tabular}{clcc}
\hline $\begin{array}{c}\text { Laboratory } \\
\text { Sample }\end{array}$ & $\begin{array}{c}\text { DSDP Sample } \\
\text { (interval in cm) }\end{array}$ & Sulfide-S & $\begin{array}{c}{ }^{34} \mathrm{~S}(\%) \\
\text { "Pyrite-Sulfate"-S }\end{array}$ \\
\hline 3043 & $424 \mathrm{~B}-5-1,58-61$ & +0.1 & nd \\
3044 & $424 \mathrm{~B}-5-1,88-91$ & -0.6 & nd \\
3045 & $424 \mathrm{~B}-5-2,11-15$ & -0.1 & nd \\
3046 & $424 \mathrm{~B}-6-1,8-10$ & 0.0 & +4.0 \\
3047 & $424 \mathrm{~B}-6-1,55-58$ & +0.6 & nd \\
3049 & $424 \mathrm{C}-2-1,19-23$ & -0.1 & nd \\
3050 & $424 C-3-1,52-56$ & +0.5 & +4.5 \\
3051 & $425-7-1,30-34$ & -6.6 & -13.0 \\
3052 & $425-7-1,99-101$ & 0.0 & nd \\
3053 & $425-7-1,133-135$ & 0.0 & nd \\
3054 & $425-7-2,74-77$ & +1.1 & +2.1 \\
3055 & $425-7-2,107-112$ & -2.9 & +0.2 \\
3056 & $425-8-1,39-42$ & -3.5 & +2.1 \\
3057 & $425-8-1,97-100$ & +0.9 & +3.2 \\
3058 & $425-8-1,142-144$ & +0.5 & nd \\
3059 & $425-9-1,74-76$ & +0.9 & nd \\
3061 & $425-9-1,134-137$ & +0.6 & nd \\
3062 & $425-9-2,27-30$ & +0.3 & +7.7 \\
3063 & $425-9-2,118-121$ & +1.9 & +2.8 \\
3064 & $425-9-3,73-77$ & +0.8 & +5.0 \\
\hline
\end{tabular}

diagram) and "pyrite-sulfate" sulfur (right side) are shown in a frequency distribution plot in Figure 2.

The sulfide sulfur values show slight variations around the zero value of the $\delta$ scale-that is, the sulfur isotope value of meteritic sulfur. Mean values range from $-0.2 \%$ (Hole $506 \mathrm{G}$ ) to $-0.35 \%$ (Hole 507B), with a slight enrichment of the heavier isotope ${ }^{34} \mathrm{~S}$ at Site $425(+0.05 \%)$. The "pyrite-sulfate" sulfur has a much broader range of values $(-19.5 \%$ o to $+9.7 \%$ ) than does the sulfide sulfur.

\section{Sulfur Content}

\section{DISCUSSION}

As shown in Figure 1, sulfur content is positively correlated with iron content, though in almost all cases it is below the line determined by Mathez (1976) for sulfide- 


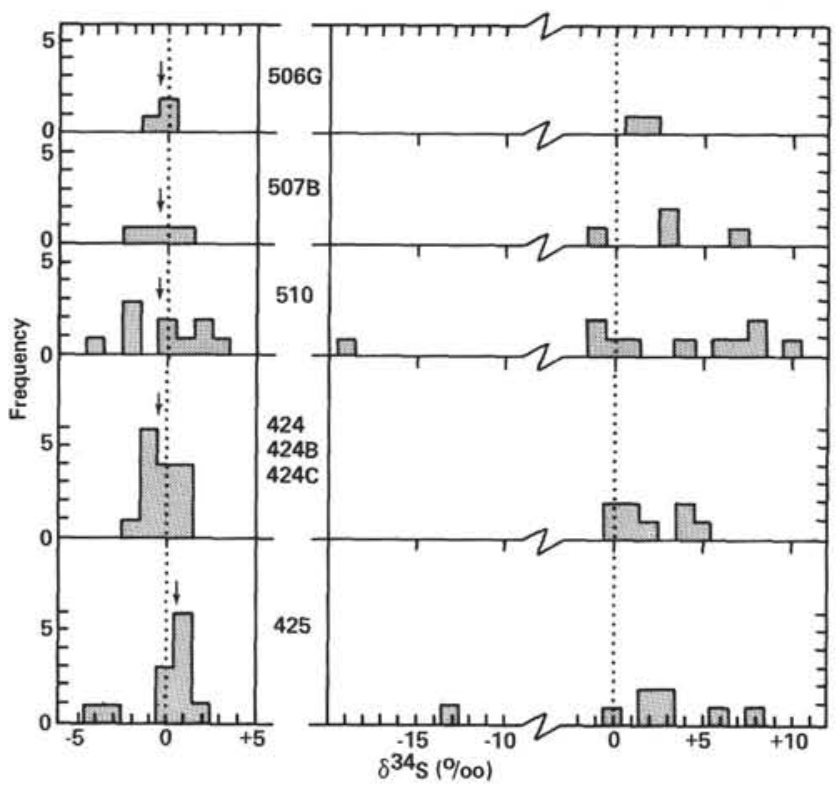

Figure $2 . \delta^{34} \mathrm{~S}$ values for all samples analyzed from the Galapagos Rift (Legs 54 and 70), given in a frequency distribution plot. Left set of diagrams are sulfur isotope values for sulfide sulfur (arrows indicate mean values); right set of diagrams are sulfur isotope values for "pyrite-sulfate" sulfur.

saturated deep-sea basalt glasses. Irregardless of how the covariance between iron and sulfur is indicated by the figure, low sulfur concentrations can result from two main processes:

1) The interior of pillows is depleted in sulfur relative to the rim, the sulfur having possibly escaped along cooling fractures (Moore and Fabbi, 1971). Because a certain minimal amount of material is required for sulfur isotope determinations, I have never selected samples from the (rare) glassy pillow margins.

2) During the low-temperature oxidative alteration of basalts, igneous sulfides are oxidized to such unstable soluble sulfur species as $\mathrm{SO}_{3}{ }^{-2}$ and $\mathrm{S}_{2} \mathrm{O}_{3}{ }^{-2}$ (Andrews, 1979). The decomposition of these compounds through disproportionation may result in the formation of pyrite and the generation of $\mathrm{SO}_{4}{ }^{-2}$, which will be removed from the system.

For the relatively fresh basalts from the Galapagos Rift, the second process seems to be less important, as judged by petrological and chemical evidence. The variable (lower) sulfur content can be explained by the fact that the samples were taken at different distances from the outer pillow rims.

\section{Sulfur Isotopes}

The isotope values of the sulfide sulfur for the samples at all the Galapagos sites do not significantly fluctuate around the zero value of the $\delta$ scale (Fig. 2).

Except for a slight enrichment in ${ }^{34} \mathrm{~S}$ of about $0.3 \%$ 。 at Site 425 , all the sites show approximately the same mean value $(-0.3 \%)$, irrespective of whether they belong to normal (old) Galapagos crust or to the young FETI-basalts. Further, there is no correlation between sulfur content and sulfur isotope composition. In the first step of the preparation method, only the igneous sulfides were disintegrated (e.g., pyrrhotite, chalcopyrite, and other sulfides of the $\mathrm{Fe}-\mathrm{Cu}-(\mathrm{Ni})-\mathrm{S}$ system); sulfate sulfur and pyrite were not attacked. Therefore, in most cases, the results represent the isotope value of primary igneous sulfur, which may have changed isotopically either as a result of alteration or of kinetic effects caused by diffusion processes during the quenching of the lava. Since we cannot observe any tendency toward isotope fractionation on the basis of the mean sulfur content at different sites, the sulfur source should be isotopically similar for the less developed tholeiites from older sites as well as for the younger FETI-basalts.

Furthermore, since one observes no systematic shift in isotopic composition with decreasing sulfur content at the same site (assuming a similar initial sulfur content for different samples from the same site because of the iron-sulfur covariance), the kinetic isotope effect caused by diffusion of sulfur cannot be very important.

From the sulfide sulfur data, one can conclude that the isotope composition of sulfur in the upper mantel is about $-0.3 \%$ in the region of the Galapagos Rift. Kanehira et al. (1973) argued for a slightly ${ }^{34} \mathrm{~S}$-enriched sulfur isotope composition of mantel sulfur on the basis of their analyses of three abyssal tholeiites from the Mid-Atlantic Ridge.

Figure 3 compares data on sulfur isotopes from different regions (Schneider [1970]: continental tholeiites and alkali olivine basalts; Puchelt and Hubberten [1980]: Bermuda Rise; Hubberten and Puchelt [1980]: part of East Pacific Rise; Saudi Arabia and most of the data for East Pacific Rise are from my own unpublished reports; Hubberten (in press): Costa Rica Rift.) The sulfur isotope systematics of all investigated tholeiites, oceanic or terrestrial, fall in a very narrow range (between -0.01 and $-0.4 \%$ ). With respect to the data in Figure 3 , I suggest a slightly negative sulfur isotope value for typical oceanic tholeiites, independent of their source.

An enrichment in ${ }^{34} \mathrm{~S}$ will probably occur in more fractionated rocks (Wedepohl and Muramatsu, 1979;

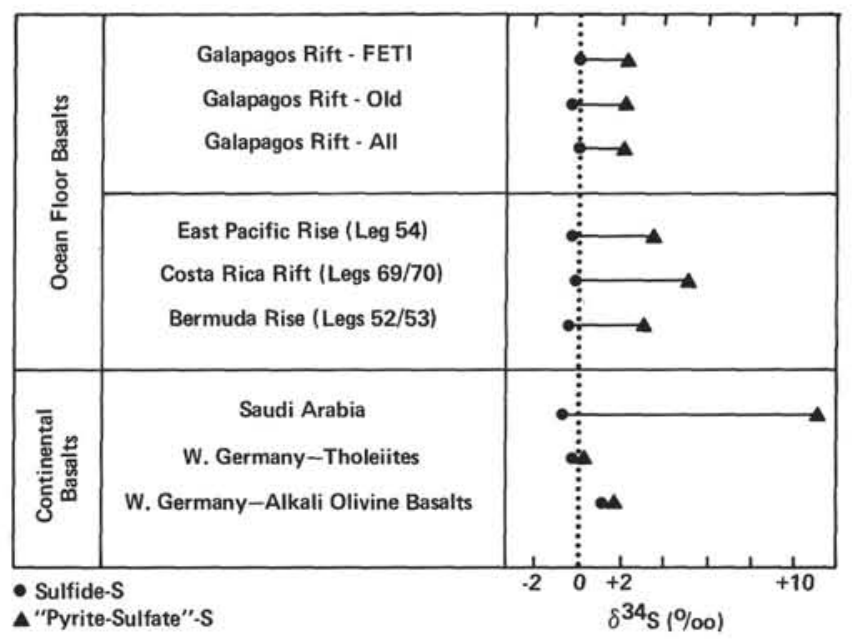

Figure 3. Comparison of sulfide sulfur $(\bullet)$ isotope ratios, and "pyrite-sulfate" sulfur $(\boldsymbol{\Delta})$ isotope ratios from continental basalts and oceanic tholeiites from various regions. (For source of data see text.) 
Hubberten and Puchelt, 1980) as shown, for example, by Schneider (1970) for alkaline olivine basalts.

In the second step of the preparation, possibly occurring secondary pyrite and sulfates are disintegrated and result in the "pyrite-sulfate" fraction. This fraction is more sensitive to secondary influences such as pyrite formation (epithermal or biogenic) or addition of seawater-derived sulfate. Because of the amount of sulfur introduced into the system, these secondary processes easily overprint the primary sulfate that occurs as traces in basalts (Schneider, 1970).

At the temperatures when basalt solidifies, sulfate sulfur in equilibrium with sulfide sulfur should give isotope values between +2 and $+4 \%$ (Sakai, 1957). In some of the samples I studied, the "pyrite-sulfate" sulfur lies in this range and could, therefore, represent primary sulfate.

Most of the samples are either slightly enriched or depleted in ${ }^{34} \mathrm{~S}$ as compared to the theoretical value, which is indicative of secondary influences such as the addition of seawater-derived sulfate or the formation of secondary pyrites.

\section{ACKNOWLEDGMENT}

This investigation was supported by a grant from the Deutsche Forschungsgemeinschaft, Bonn. The manuscript was reviewed by Prof. Dr. J. Hoefs (Göttingen) and Prof. Dr. H. Puchelt (Karlsruhe), who made valuable suggestions. Dr. D. E. Large (Braunschweig) improved the English. J. Erzinger and A. Hass carried out the sulfur content determinations, and E. Weiher assisted greatly in preparing the samples for the isotope measurements.

I want to thank all individuals and institutions who helped in the investigations and in the preparation of this paper.

\section{REFERENCES}

Andrews, A. J., 1979. On the effect of low temperature seawaterbasalt interaction on the distribution of sulfur in oceanic crust, layer 2. Earth Planet. Sci. Lett., 46:68-80.

Czamanske, G. K., and Moore, J. G., 1977. Composition and phase chemistry of sulfide globules in basalts from the Mid-Atlantic Ridge rift valley near $37^{\circ} \mathrm{N}$ lat. Geol. Soc. Am. Bull., 88:587-599.

Emmermann, R., and Puchelt, H., 1980. Major and trace element chemistry of basalts from Holes 417D and 418A, Deep Sea Drilling Project Legs 51-53. In Donnelly, T., Francheteau, J., Bryan, W.,
Robinson, P., Flower, M., Salisbury, M., et al., Init. Repts. $D S D P, 51,52,53$, Pt. 2: Washington (U.S. Govt. Printing Office), 987-1000.

Grinenko, V. A., Dmitriev, L. V., Migdisov, A. A., and Sharas'kin, A. Ya., 1975. Sulfur content and isotope compositions for igneous and metamorphic rocks from mid-ocean ridges. Geochem. Int., 12:132-137.

Hubberten, H. W., and Puchelt, H., 1980. Zur Schwefelisotopengeochemie basaltischer Gesteine. Zentr. Inst. f. Isotope, Mitt., 30: 80-90.

Hubberten, H. W., in press. Sulfur content and sulfur isotopes of basalts from the Costa Rica Rift (Hole 504B, DSDP Legs 69 and 70). In Langseth, M. G., Cann, J. R., et al., Init. Repts. DSDP, 69: Washington (U.S. Govt. Printing Office).

Kanehira, K., Yui, S., Sakai, H., and Sasaki, A., 1973. Sulphide globules and sulphur isotopes ratios in the abyssal tholeiite from the Mid-Atlantic Ridge near $30^{\circ} \mathrm{N}$ lat. Geochem. J., 7:89-96.

Lange, J., and Brumsack, H. -J., 1977. Total sulphur analysis in geological and biological materials by coulometric titration following combustion. Anal. Chem., 286:361-366.

Mathez, E. A., 1976. Sulfur solubility and magmatic sulfides in submarine basalt glass. J. Geophys. Res., 81:4269-4276.

Moore, J. G., and Fabbi, B. F., 1971. An estimate of the juvenile sulfur content of basalt. Contrib. Mineral. Petrol., 41:105-118.

Ohmoto, H., 1972. Systematics of sulfur and carbon isotopes in hydrothermal deposits. Econ. Geol., 67:551-578.

Puchelt, H., and Hubberten, H. W., 1980. Preliminary results of sulfur isotope investigations on Deep Sea Drilling Project cores from Legs 52 and 53. In Donnelly, T., Francheteau, J., Bryan, W., Robinson, P., Flower, M., Salisbury, M., et al., Init. Repts. DSDP, 51, 52, 53, Pt. 2: Washington (U.S. Govt. Printing Office), $1145-1148$.

Ricke, W., 1964. Präparation von Schwefeldioxid zur massenspektrometrischen Bestimmung des Schwefel-Isotopenverhältnissess ${ }^{32} \mathrm{~S} /{ }^{34} \mathrm{~S}$ in natürlichen Schwefel verbindungen. Z. Anal. Chem., 199:401413.

Sakai, H., 1957. Fractionation of sulfur isotopes in nature. Geochim. Cosmochim. Acta, 12:150-169.

Schneider, A., 1970. The sulfur isotope composition of basaltic rocks. Contrib. Mineral. Petrol., 25:95-124.

Srivastava, R. K., Emmermann, R., and Puchelt, H., 1980. Petrology and geochemistry of basalts from Deep Sea Drilling Project Leg 54. In Rosendahl, B. R., Hekinian, R., et al., Init. Repts. DSDP, 54: Washington (U.S. Govt. Printing Office), 671-693.

Thode, H. G., Monster, J., and Dunford, H. B., 1961. Sulfur isotope geochemistry. Geochim. Cosmochim. Acta, 25:159-174.

Wedepohl, K. H., and Muramatsu, Y., 1979. The chemical composition of kimberlites compared with the average composition of three basaltic magma types. Proc. Second Intern. Kimberlite Conf., 1:300-312. 